\title{
Universiteit
}

Leiden

The Netherlands

\section{Education for All as praxis: consequences for the profession}

Ponte, Petra; Smit, Ben H.J.

\section{Citation}

Ponte, P., \& Smit, B. H. J. (2013). Education for All as praxis: consequences for the profession.

Professional Development In Education, 39(4), 455-469. doi:10.1080/19415257.2013.796296

Version: $\quad$ Publisher's Version

License: $\quad$ Leiden University Non-exclusive license

Downloaded from: https://hdl.handle.net/1887/3274283

Note: To cite this publication please use the final published version (if applicable). 


\section{Education for All as praxis: consequences for the profession}

\section{Petra Ponte \& Ben H.J. Smit}

To cite this article: Petra Ponte \& Ben H.J. Smit (2013) Education for All as praxis: consequences for the profession, Professional Development in Education, 39:4, 455-469, DOI: $10.1080 / 19415257.2013 .796296$

To link to this article: https://doi.org/10.1080/19415257.2013.796296

册 Published online: 02 Jul 2013.

Submit your article to this journal $\asymp$

山ll Article views: 433

Q View related articles $\asymp$

4 Citing articles: 2 View citing articles 


\title{
Education for All as praxis: consequences for the profession
}

\author{
Petra Ponte ${ }^{\mathrm{a}, \mathrm{b} *}$ and Ben H.J. Smit ${ }^{\mathrm{c}}$ \\ ${ }^{a}$ Research Institute for Professional Practice, Learning and Education (RIPPLE), Charles \\ Sturt University, Wagga Wagga, NSW, Australia; ${ }^{b}$ Faculty of Education and Social Work, \\ University of Sydney, Sydney, NSW, Australia; ${ }^{c} I C L O N$, Leiden University Graduate School \\ of Teaching, Leiden, The Netherlands
}

(Received 20 February 2013; final version received 12 April 2013)

\begin{abstract}
In this paper we explore the concepts that form the framework for the different research projects that are reported in this special issue. All projects were part of the international Pedagogy, Education and Praxis research network. The main goal of this paper is to set the theoretical 'mis-en-scène' for the other papers in the issue. First, based on literature, we explore different meanings of concepts such as 'Education for All', 'social justice', 'praxis' and 'pedagogy'. Secondly, we explain why we rely on these concepts and, finally, we investigate the consequences of these decisions for the profession, including professionals in schools as well as in universities.
\end{abstract}

Keywords: Education for All; educational praxis; pedagogy; social justice

\section{Differences between children as the norm and not the exception}

The right to education - on the basis of equality of opportunity - is one of the formal and legally binding human rights set down in various declarations and legal conventions. The foundation for the right to education was embodied in the Universal Declaration of Human Rights in 1948, and then subsequently in the European Convention on Human Rights in 1954, the Declaration of the Rights of the Child in 1959 and the International Convenant on Civil and Economic Rights in 1966.

The human rights set down in these conventions and declarations are conceived by Nickel (1987) as public moral norms that aim to secure, for individuals, the necessary conditions for leading a minimally good life. These minimal rights are universal; that is to say, they apply to everyone worldwide without exception. However, children were not initially considered to hold these rights. That only came later, on 20 November 1989, when the General Assembly of the United Nations ratified the UN Convention on the Rights of the Child.

The Convention has been ratified by almost all countries in the world, except the USA (because the Convention prohibits the death penalty for minors) and Somalia (because there was no government personnel in that country able to sign it). Since ratification, all countries have had a duty to observe the agreements. The most important principles behind these agreements are as follows:

*Corresponding author. Email: petra.ponte@actieonderzoek.com 
(1) The principle of non-discrimination, in the sense that all rights are applicable to all children without any form of discrimination whatsoever, regardless of race, skin colour, sex, language, religion, political or other convictions, national, ethnic or social origin, financial resources, disability, birth or other circumstance of the child or of his or her parents or legal guardians.

(2) The principle that the best interests of the child must guide any decision taken in connection with the education of children.

(3) The principle that every child has the right to life, survival and development to its maximum potential.

(4) The principle that children have the right to express their views in all matters affecting them and for their views to be given due weight in accordance with their age and maturity.

'These underlying principles', according to UNICEF/UNESCO, 'make clear a strong commitment to ensuring that children are recognised as active agents in their own development and that education is designed to promote and respect their rights and needs' (2007, p. 8). The right to education is therefore defined in terms of universality, participation, respect and inclusion.

In 1990 the Education for All movement was launched at the World Conference in Jomtien, Thailand. Representatives from 155 countries and 150 organisations pledged to provide Education for All by the year 2000 via the EfA Fast Track Initiative. UNESCO has been mandated to lead the movement and coordinate the international efforts to achieve Education for All. In the text Education for All: Meeting our Collective Commitments, adopted by the World Education Forum in Dakar (Senegal) in 2000, the aim of the Education for All movement was re-established:

We re-affirm the vision of the World Declaration on Education for All (Jomtien 1990), supported by the Universal Declaration of Human Rights and the Convention on the Rights of the Child, that all children, young people and adults have the human right to benefit from an education that will meet their basic learning needs in the best and fullest sense of the term, an education that includes learning to know, to do, to live together and to be. It is an education geared to tapping each individual's talents and potential, and developing learners' personalities, so that they can improve their lives and transform their societies. (UNESCO 2000, p. 8)

Consequently - unlike what many still think - Education for All is not about a policy for specific target groups, such as students with special needs, but about the proactive creation of tailor-made education, where differences between children are the norm and not the exception. It is 'Education-for-All-by-All' and therefore - as the contributions in this special issue illustrate - it constitutes the fundamental responsibility for all those working in the profession, whether in schools, universities or policy.

With respect to this fundamental responsibility, inclusion is seen by UNESCO as a rights-based approach to education, with the recognition that full realisation of this right is not merely a question of access, but rather is a holistic approach. This approach encompasses: access to education; the right to educational quality; and the right to respect for human rights in the learning environment. Article 29 of the UN Convention on the Rights of the Child implies the need for education to be child-centred, child-friendly and empowering. It demands the attention of schools, 
universities and policy to the content of the curriculum as well as to the nature of the teaching, and to the quality of the learning environment.

\section{Having or doing?}

Although children's rights as such date from quite recent times, people have been thinking about the position of children in education from time immemorial. The Enlightenment made this thinking much more explicit, although educational ideas were not so much inspired by formal political and legal motives (as is usually the case with children's rights) but more by philosophical issues. Nowadays, political and legal motives are more dominant. In this respect, Verhellen et al. (1999/2000) note some important shifts in the rights of the child and the Education for All movement compared with earlier declarations of human rights:

It is important to note that there has been a shift from a reactive (defensive) dynamic to a proactive (offensive) dynamic. This means that attention is no longer only directed at combating violations of human rights, but is also aimed at bringing about more respect for human dignity [...] We also see that the conversion of the declarations into legally binding conventions is accelerating all the time. This provides the moral intentions with a statutory basis on which people can act. (1999/2000, p. 366; authors' translation)

Verhellen et al. (1999/2000) conclude from this that the convention aims to coerce respect for the rights of the child by legal means. They are right to question the extent that this coercion is possible. Offering pupils equal opportunities to highquality education implies both a legal-political task for the government and an educational task for those working in educational practice. Legal-political guidelines in the form of rights of the child are very important. They contribute to the definition of the essential preconditions - to be realised by government - within which teacher educators, teachers and pupils work (such as free access to education, accessibility of schools, minimum frameworks for the curriculum, investment in teacher education, mechanisms for claiming rights). However, legal-political guidelines are by necessity general and open to multiple interpretations. They are not intended as concrete instructions for practice, certainly not if that practice is in education, in which situation-specific and individualised normative and moral choices constantly have to be made when deciding how to act. Legal-political guidelines in the form of rights of the child are about frameworks and basic assumptions that remain valid and useful over a long period of time and in many different contexts. In the case of UN declarations and conventions, there are always compromises that have to be endorsed by almost 200 countries with many diverse and different cultural backgrounds. This means that while the formal rights of the child can indeed give out a strong educational message, they cannot prescribe the form that Education for All will ultimately be given in concrete educational practice.

The key question for us, then, is what mechanisms in the daily thinking and actions of teacher educators, teachers and pupils lead to just education. In their contribution to this special issue, Laurette Bristol and Petra Ponte examined this question through the lens of Young's (1990) social justice theory. Young distinguishes between approaches that mainly see democracy and social inclusion as 'having' and approaches that mainly see them as 'doing'. The 'having' perspective refers to legal and material rights that are distributed and can be 'consumed': work 
and income, healthcare, social services and education. Young argues that this perspective is necessary but too limited, because the processes that lead to dominance and oppression are not taken into consideration. That is why she adds the 'doing' perspective, referring to something that has to be realised within interpersonal interactions and which is geared to participation and self-determination:

It includes any structures or practices, the rules and norms that guide them and the language and symbols that mediate social interactions within them, in institutions of state, family and civil society as well as workplace. These are relevant to judgments of justice and injustice in so far as they condition people's ability to participate in determining their actions and their abilities to develop and exercise their capacities. (Young 1990, p. 22)

When translated to Education for All, the 'having' perspective emphasises the material function of education. It restricts discussions about inclusion to the allocation of resources to specific groups of pupils, such as special needs education, counselling services and personal budgets for children with special educational needs. De Winter (1995) calls this 'provision policy', in which children are seen as the 'objects' of care rather than co-constructors of their own lifeworld. The 'doing' perspective emphasises the inherent moral significance of education for all pupils. It analyses inclusion in terms of communication processes and human relationships. This perspective allows us to understand how well-intended help sometimes leads to oppression and dominance; how the unconscious suppositions and reactions of people who mean well lead to subtle processes of marginalisation. In consonance with the having and doing perspective, Verhellen et al. (1999/2000) argue that:

It is important to note that these rights [...] cannot be safeguarded merely by establishing formal rules and agreements. Recognition of a legal status for children in education refers to being mindful of the quality of the interaction in the context of the school, but that recognition is not an automatic indicator of increasingly respectful relationships between all parties concerned. The attitude and mentality of all who are involved with [...] children and their parents is crucially important. (1999/2000, p. 338; authors' translation)

This is where we come up against the limits of the desire to achieve educational aims through political-legal coercion, which does not allow for the realisation of respect in the educational relationship between teacher and pupil; the educator and student. The realisation of that relationship is praxis; that is, a socially embedded situation - limited in time and space - in which the adult purposefully tries to help the child to become an adult or - in education - the teacher educator or teacher tries to teach the students something. 'Trying to teach them something' is always connected with normative and moral assumptions about 'what is' (What is actually happening?), 'what ought to be' (Where should that lead now and in future?) and how to develop from 'what is' towards 'what ought to be' (Ax and Ponte 2010). These assumptions are connected with historically and culturally determined views about humanity (Ponte and Ax 2009, Biesta 2010, Groundwater-Smith et al. 2012).

\section{Praxis and views about humanity}

The praxis concept originates from Aristotle (1955), but was revived in the Enlightenment thinking from the seventeenth century when a number of 
philosophers developed a view about humanity that still dominates our thinking today and which made it possible for conventions on the rights of the child to be enacted. In this section we focus on these views about humanity. In the next sections we further examine the praxis concept that is central to this special issue.

The Enlightenment and humanist philosophers of the seventeenth and eighteenth centuries 'discovered' human beings as individuals who are able to influence their own lives and the context in which they live. Human beings are seen as autonomous thinkers who are able to take responsibility for their own actions. Human beings are therefore free to think what they will, without being bound by the authority of higher powers that cannot be questioned. In this outlook, therefore, everything they do is based on dialogue with themselves and with those close to them. The same freedom of thought and action also applies to the development of children. They are no longer seen as God-given or pre-determined by their social origin. In the words of Nietzsche in the nineteenth century, the human being turned out to be 'dass noch nicht fest gesteltes Tier', a creature with the capacity to learn, a creature that relies on being raised by adults.

With the discovery of human beings as autonomous individuals came the 'discovery' of the possibility and need to raise children in certain ways. Kant, for instance - one of the most influential philosophers of the modern age - contended that human beings only become human through their upbringing. He argued that human beings are not determined by inborn instincts or divine powers, but essentially by their capacity for autonomous moral judgement and actions. Human beings fulfil themselves as creatures of pure reason and so they need to be brought up with an ethical-moral outlook. The main task is to bring up children to be virtuous people and that does not happen as a matter of course. It was from the 'discovery' of human beings as autonomous individuals who are dependent on their upbringing that pedagogy as 'human science' or, more precisely, 'the science of the child's upbringing' developed. It is a science with strong German roots, traditionally dominant in many European countries (particularly in the north and east, including Belgium, Germany, the Netherlands and Finland) (Ponte 2007, Ax and Ponte 2010, Biesta 2010).

In their contribution to this special issue, Carlos van Kan, Petra Ponte and Nico Verloop describe continental European pedagogy as the science that studies the child's upbringing in different domains, such as education, social work, child welfare and law (for example, van Manen 1994, Ponte 2007, Ax and Ponte 2010). In continental Europe, pedagogy is a separate discipline apart from, for example, philosophy, psychology and sociology, often located in separate departments within university faculties. The discipline seeks answers to questions about what kind of human beings children are, what kind of human beings children should become (and for what kind of society) and how they can be raised toward becoming such human beings, taking into account the context in which this process of upbringing takes place. In the ongoing academic debates, researchers take different positions based on the paradigm or approach they put themselves in; the empirical-analytical, humanistic, phenomenological or critical pedagogy ('pedagogiek'). Van Kan, Ponte and Verloop study how teachers relate to this debate on the basis of the question how teachers connect their daily classroom interactions ('what is') to what they think is in the pupil's best interest ('what ought to be') in their own educational terms. 
Since the discovery of human beings as autonomous individuals during the Enlightenment, child-rearing has been seen as a necessary human endeavour, one in which people could no longer rely on an indisputable religious authority, a predetermined human destiny or pre-determined social relationships. Now the human being is seen as malleable and as a creature that can be shaped. This optimistic view of human nature can be understood as a reaction against the dominant view up to that time, and the writings about upbringing that had seen its aims as being derived in a direct line from deterministic, mainly religious, notions about humankind. This change in thinking about human beings re-emerges in the documents of UNICEF/UNESCO and the Education for All conventions (UNICEF/UNESCO 2007). For the first time we see the right to:

- participation ('All children are entitled to express their views and have them given due weight. This involves listening as well as talking. It requires that children play a part in the creation of constructive spaces that promote mutual respect [amongst pupils themselves and between teachers and their pupils]'; UNICEF/UNESCO 2007, p. 22);

- information ('In order to claim rights, people need to know what their rights are and how they are being addressed, how decisions are made and by whom, and what mechanisms, if any, exist to seek redress in cases of violations'; UNICEF/UNESCO 2007, p. 17);

- empowerment and capacity-building ('the goal is to give people the power and capacities to change their own lives, improve their own communities and influence their own destinies'; UNICEF/UNESCO 2007, p. 11).

What comes to the fore in these elements of the convention is that, in contrast to the dominant vision in earlier times, children are no longer seen as incomplete adults but as young people in a specific phase of their life, as Meuwese et al. (2005) state:

The convention is the expression of an understanding of what children are, and understanding that starts with the recognition that children are people, people in the process of growing up, but not in the process of becoming people. Children are not little adults, but people on a journey towards adulthood. (2005, p. 1; authors' translation)

\section{The intractability of praxis}

The change in thinking about children as human beings is visible in the conventions and declarations referred to in the previous sections. The child itself has now become a holder of rights. However, holding rights does not automatically mean that they will be honoured. The governments that have ratified the conventions and declarations have a duty to ensure that these rights, including the right to education, are fulfilled. UNICEF/UNESCO (2007) therefore feels the need for 'a breakthrough from the rhetoric of the "right to education" to concrete and accelerated interventions at the policy and programme levels for attaining the EfA [Education for All] goals [...]' (p. vii). Equally, UNICEF/UNESCO observes that praxis is intractable. In other words: the Education for All goals have always to be realised in a complex, restraining and obstinate environment in which the participation, information and empowerment that are aimed for are not being achieved everywhere. The 2007 document concludes with this sharp criticism: 
There has been a failure to acknowledge the complexity of the barriers impeding children's access to school, to listen to the concerns expressed by children themselves concerning their education, to build a culture of education in which all children are equally respected and valued, to engage parents and local communities in supporting education, to embrace a holistic approach to education, to address children's rights in education or to embed schools as vibrant centres for community action and social development. (UNICEF/UNESCO 2007, p. 2)

In his contribution to the special issue, Ben Smit explores this holistic approach to education on the basis of the multi-tiered levels of student participation in education, in particular the student-as-researcher approach. He concludes that - as applies to all reforms in educational processes and practices - enabling student participation requires effort and commitment of all stakeholders and may take a long time before it consolidates into a standing practice. New practices and ways of working have to be introduced and accepted, adults and young people have to be encouraged to support participation activities and ensure they have influence, and new roles and responsibilities have to be negotiated and adopted. Smit describes student participation as not being a product of a one-shot event; it can be seen as a process that mirrors itself in the school culture (shared ideas, habits and imaginations) and organisation, and in teachers' beliefs, attitudes and actions.

The intractability of praxis when it comes to realising the Education for All goals, then, is certainly not only a matter of concern in developing countries. In the current neo-liberal climate in the western world - with its emphasis on performance, efficiency, excellence in education and its declining tolerance of the multicultural society - Education for All is under pressure. While few people will, for instance, protest against the phrase that 'children must be educated to become democratic citizens', the current neo-liberal rhetoric would have us believe that education is mainly concerned with training and lifelong learning for the labour market, so education for the sake of economic benefits (Magalhães and Stoer 2009). These kinds of choices made in education policy are not choices with no strings attached; they have an enormous impact on pupils' lives.

\section{Praxis as promise and project}

Studying Education for All as praxis helps us to explore the underlying mechanisms that are at stake here; that is, to understand Education for All as a social situation characterised by tensions between intentions and consequences, the conscious and unconscious, the intentional and unintentional, as well as tensions between theory and practice, individual (teacher educator, teacher and the pupils) and society. Therefore, Education for All as praxis can above all be understood, according to Gadotti (1996), as a never-ending endeavour of all stakeholders who commit themselves to:

[...] educate individuals as a point on the horizon, but never a finished process because education is really an unending process. Educationists look forward to a new reality which does not exist and probably will never be fully realised, but which they nevertheless wish to create. Education is at the same time promise and project. (1996, p. 7)

Many who see the concept of praxis as central to the endeavours of education have drawn upon the wisdom of Aristotle, including: Carr and Kemmis (1986), in 
their oft-quoted work Becoming Critical; Oancea and Furlong (2008) in their discussion of quality criteria in educational research; and Ax and Ponte (2008; see also Groundwater-Smith et al. 2012) whose work is discussed in this section. Van Bons and Ophuijsen (1999) summarise Aristotle's definition of praxis as:

\begin{abstract}
'action' referring, in a general sense to all intentional activities, by which people can reach a particular goal through their own efforts. More specifically, the term refers to rational action based on a conscious choice [...] and action is defined as the product of observation, desires, and intellect or reason [...]. The inclusion of reason means that action in the narrow sense is the preserve of adults, who are most complete when they are engaged in action and who achieve 'happiness' through action. (1999, p. 340; authors' translation)
\end{abstract}

Aristotle's concept of praxis could be interpreted as psychological. He starts from the premise that human beings are inclined 'to do good' thanks to their natural capacity for reason. Praxis is the purposeful and self-accountable action of the individual who is 'trying to do good' in order to reach happiness. In his view there is also 'non-praxis'; that is, 'not trying to do good'. Enlightment philosophers in the eighteenth and nineteenth centuries renewed the interest in praxis. In Kant's moral philosophy, however, we see that he does not use praxis so much as a psychological category, but rather as an epistemological category. He sees praxis as intentional and rational action by which normative judgements should be validated: 'How can I validate this moral claim as just or unjust?' This is deliberative rationality that in his view is obtained through pure reasoning by individuals. Deliberative rationality was reformulated by critical theory in the twentieth century, when praxis became a framework for sociological critique and critical educational theories (Freire 1972, Gadotti 1996, Ax and Ponte 2008, 2010, Ponte and Ax 2011). As a framework for critique it had major implications for our understanding of Education for All. To support the position taken in this paper, four arguments are put forward.

First, in contrast to Aristotle's idea that a social situation can be defined as praxis or not praxis, we suggest that every concrete social situation has mores and so by definition can be critically evaluated through the lens of praxis, no matter what the nature of the action is. Here we quote Gadotti (1996), who - in line with this argument - states that:

The kind of education that copies models, that wishes to reproduce models, does not stop being praxis, but is limited to a reiterative, imitative, and bureaucratized praxis. Quite different from this, transforming praxis is essentially creative, daring, critical, and reflective. (1996, p. xvii)

Second, the critical understanding of praxis as framework supposes deliberative rationality but, unlike Kant, Habermas sees deliberative rationality as obtained by communicative action; it is not an individual, but an intersubjective endeavour.

Third, by saying that these initiatives to realise Education for All are praxis, we claim that we basically explore actions of the different stakeholders in reciprocal relations with the cultural, social and political contexts in which they act.

Finally, in understanding the relationship between human action and the cultural, social and political contexts in which human action takes place, praxis does not refer only to individual psychological intentions 'to do good' (as in the Aristotelian 
definition), but also to social - sometimes unintended, hidden or manipulative consequences in terms of social equity, justice and solidarity.

Raudenbush (2009), for instance, took findings from diverse empirical studies to argue that it is especially children with special needs and children from the lower social classes who benefit enormously from good education, but that these pupils by no means always have access to good education. They usually spend fewer years in school and are generally taught by less experienced teachers, showing that the principle of social inclusion is still more an ambition than a reality.

Recent European research (Detting and Becker 2009) has also shown that the second generation of immigrant children in the Netherlands are doing considerably less well than their peers in neighbouring countries. That is thought to be mainly due to the dual structure of the Dutch education system, where pupils in pre-vocational secondary schools were only entitled to a maximum of five years' secondary schooling until recently, and also had little chance of successfully transferring to a senior secondary vocational school. It is not difficult to imagine that this situation can be frustrating and hurtful for pupils; it is also not difficult to imagine that many of these pupils turn against education and all that comes with it.

\section{Professional scope for autonomous action and rational decision-making in praxis}

The praxis concept presented in the previous section offers a useful framework, but this still leaves unanswered the question of whether Education for All should be interpreted mainly from the standpoint of practitioners who are capable of acting autonomously and rationally, or mainly from the cultural, social and political contexts in which they act. The first standpoint is represented by lifeworld as seen in the phenomenological theory of Schutz (Schutz and Luckmann 1973), and the second by the system theory of Luhmann (1995). However, the understanding of praxis that is presented in this paper is strongly inspired by Habermas (1981), who tries to overcome this duality. He argues that neither lifeworld theories nor system theories are sufficient to understand social phenomenona. Instead, social situations should be interpreted as resulting from the interplay of both forces, and we hold this to be true in relation to Education for All.

Below it will be argued that this interplay conditions teacher educators' and teachers' ability to realise socially just education in their daily work. From the contributions in this special issue we learn that their abilities are determined by two conditions: the scope they are given in educational praxis to act autonomously and to take decisions with regard to the aims of their actions. Ax and Ponte (2008, pp. 1-21) - whose line of argument will be followed in the rest of this section explored this by combining Habermas' concepts of lifeworld and system with the distinction that Mannheim (1940) (in line with Weber [1946], first published in 1902-1924) made between functional and substantive rationality. In order to understand their argument, first both theories will briefly be looked at.

\section{Scope of action: lifeworld and system}

With Habermas' concepts of lifeworld and system, the professional scope to act autonomously can be problematised. System in Habermas' theory is the way the world is organised; it has self-regulating dynamics with anonymous mechanisms, over 
which individuals have little or no influence. System is driven by economic, legal, administrative and bureaucratic subsystems. Habermas argues that in modern societies system is increasingly uncoupled from its foundations in lifeworld, foundations that are necessary for shared sense-making, fair social relationships and mutual solidarity.

Lifeworld is the domain where people organise their own reality, based on their own preferences and in dialogue with others. Lifeworld in current times is increasingly being colonised by system in which power and money are the dominant mechanisms, according to Habermas. We see this in education where the autonomous scope to act seems to be reduced more and more, under pressure from increasing standardisation and bureaucratisation, handing over control of what happens in the school and the university to others (politicians, bureaucrats, etc.). Such colonising clearly has ramifications for Education for All.

\section{Scope of decision-making: substantive and functional rationality}

One of the dangers of standardisation and bureaucratisation is - according to many philosophers - that moral questions about whose interests various actors in social situations are acting in and where that action should lead to are in danger of no longer being discussed. In western culture there is no clear place for moral pronouncements about socially just education, and moral terms are used and distorted by different groups in such a way that they cease to have any moral meaning, Neiman (2008) argues. She asserts that 'the discovery that many of our judgements were based on assumptions the whole world does not share' (Neiman 1008, p. 14) has often led to a situation whereby many feel that it is no longer possible to make any judgements at all. She claims that, in western society, moral claims make many of us feel profoundly uncomfortable:

Wary of simplification, and even more afraid of sounding sappy, the left tends to reject not only words like true and noble, but even words like legitimate and progress, which are meant to replace them. If used at all, such words are subject to quotation marks - sometimes called scare quotes - that express the speaker's discomfort in the ultimate postmodern gesture, fingers wiggling beside ears in a little dance that says: $I$ can use it, but I don't go so far as to mean it, and it all matters so little anyway I can make myself look silly to boot. What matters is putting distance between you and your beliefs. (Neiman 2008, p. 18; emphasis in original)

For example, the current spending cuts in special education in the Netherlands are mainly inspired by economic considerations: efficiency above all. The policy aims to achieve the highest possible returns for the least possible cost. Moral principles or judgements about how these policy measures are working out in practice play no role in this; at least, they are not being put forward to substantiate the measures.

This example requires us to turn for our purposes to a more finely tuned distinction with regard to rationality, which is the one that Mannheim (1940), with reference to Weber (1946, first published in 1902-1924), makes between 'functional rationality' and 'substantive rationality'.

Functional rationality concerns the instrumental decisions about rules, methods, strategies and techniques that are needed to reach specific goals; goals set by others. Of greatest concern in this rationality is the functional usefulness of possible actions. Which instruments do we have at our disposal? Are the measures taken effective and efficient? What works and what does not work? 
Substantive rationality, by contrast, is concerned with the desirability of the actions and the goals to be reached through those actions: of greatest concern in this rationality are the arguments that provide moral legitimacy for an action or the purpose of an action. What are our underlying values? What are our aims? What do these mean for our actual actions? Have we achieved something that is genuinely worthwhile and just?

Professionals must have the necessary degree of say about values and aims, because it is they who ultimately have to reconcile in a professional manner the diverse values and aims of the different stakeholders in education, all of which may be legitimate in themselves. This essential power to take decisions about values and aims is the substantive scope for decision-making. Substantive scope is not enough though. Professionals also need functional scope; they need to decide how those values and aims can be realised in practical terms as well. Substantive and functional rationality are two sides of the same coin. The issue at stake now is that not only are expectations of professionals' substantive rationality inflated, so are expectations of their functional rationality, and too many policy-makers believe that this rationality can also be imposed from outside by ready-made and prescribed programmes and curricula.

Combining Mannheim's substantive and functional rationality with Habermas' system and lifeworld gives us a relevant framework for understanding the professional scope for rational decision-making and autonomous action for practitioners in both schools and universities. This framework for understanding praxis can be represented in a matrix as shown in Figure 1 (see Ax and Ponte 2008, p. 15; Groundwater-Smith et al. 2012, p. 8).

It is important to emphasise that Ax and Ponte (2008) - unlike Habermas (1981), Carr and Kemmis (1986) and others - do not equate system with functional rationality nor lifeworld with substantive rationality. The relationship between professional rationality and autonomy in education is more complex than that.

System and lifeworld are not strictly partitioned: Education for All is a public enterprise and all of us working in educational praxis occupy different positions in both worlds. Moreover, individual responsibility to take substantive and functional decisions exists irrespective of system dynamics. This means that educational praxis

\begin{tabular}{|c|c|c|c|}
\hline & & \multicolumn{2}{|c|}{ Scope for Autonomous Action } \\
\hline & & System & Lifeworld \\
\hline 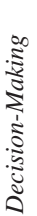 & $\begin{array}{l}\text { Substantive } \\
\text { rationality }\end{array}$ & $\begin{array}{l}\text { 1) To what extent are } \\
\text { educational aims prescribed by } \\
\text { system? Who actually are part } \\
\text { of that system? What is our } \\
\text { own role in system? }\end{array}$ & $\begin{array}{l}\text { 2) What scope do we have in } \\
\text { our lifeworld to set our own } \\
\text { aims? What opportunities exist } \\
\text { to expand that scope and are } \\
\text { we using them? }\end{array}$ \\
\hline 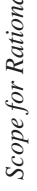 & $\begin{array}{l}\text { Functional } \\
\text { rationality }\end{array}$ & $\begin{array}{l}\text { 3) To what extent does the } \\
\text { system determine how we have } \\
\text { to achieve the aims and which } \\
\text { parts of the system make those } \\
\text { decisions? }\end{array}$ & $\begin{array}{l}\text { 4) To what extent can we } \\
\text { decide on our own rules and } \\
\text { working methods? What scope } \\
\text { do we have to do this and how } \\
\text { can we increase it? }\end{array}$ \\
\hline
\end{tabular}

Figure 1. Praxis: professional scope for autonomous action and rational decision-making. 
can be described first and foremost as a dynamic reality, meaning that the cells in Figure 1 do not represent separate spheres of influence, or a static description of reality, or a prescription of how the educational praxis should be.

The cells in Figure 1 help us to understand the issues, dilemmas and challenges for Education for All by generating questions such as the following: To what extent are educational aims prescribed by system? Who actually are part of system? What is our own role in system? (Cell 1); What scope do we have in our lifeworld to set our own objectives? What opportunities exist to expand that scope and are we using them? (Cell 2); To what extent does the system determine how we have to achieve the aims and which parts of the system make those decisions? (Cell 3); To what extent can we decide on our own rules and working methods? What scope do we have to do this and how can we increase it? (Cell 4); How far are the objectives (Cells 1 and 2) in harmony with the methods of working (Cells 3 and 4)?

\section{Sayings, doings and relatings in praxis}

To make the manifestations of the interplay between the four cells in Figure 1 visible, several authors in this special issue turned to what Schatzki (2002) called 'the site of the social' and the concept of 'practice architectures' formulated by Kemmis and his collaborators (Kemmis and Grootenboer 2008, Kemmis and Smith 2008, Kemmis et al. 2012, Kemmis 2012). This informs the contributions of Wilkinson, Forsmann and Langat (who in this issue explore some challenges, constraints and possibilities for creating inclusive multicultural practices in previously monocultural education settings); Hemmings, Kemmis and Reupert (who explore conditions shaping several kinds of practices of nine Australian university lecturers teaching inclusive education as part of the initial professional development and learning of preservice teachers); and Lange and Meaney (who explore their own decision-making in relation to setting up a professional development programme for Education for All in a rural Australian city).

Schatzki defines a social practice as 'an open, organized array of doings and sayings' (2010, p. 51). The central theme of his book The Site of the Social is to show that practices are sites of human co-existence:

The social site is a specific context of human coexistence: the place where, and as part of which, social life inherently occurs. To theorize sociality through the concept of a social site is to hold that the character and transformation of social life are both intrinsically and decisively rooted in the site where it takes place. In turn, this site-context ... is composed of a mesh of orders and practices. Orders are arrangements of entities (e.g., people, artefacts, things), whereas practices are organized activities. Human coexistence thus transpires as and amid an elaborate, constantly evolving nexus of arranged things and organized activities. (Schatzki 2002, p. xi)

Later, he describes social life in terms of 'practice-arrangement bundles', in which practices unfold amid arrangements of entities of various kinds. Following directions suggested by Schatzki's practice theory, Kemmis and Grootenboer (2008), Kemmis et al. (2012) and Kemmis (2012) have proposed that practices are composed not only of 'sayings' and 'doings', but also of 'relatings'. These are 'intersubjective' spaces, in which people can encounter one another as interlocutors, in interaction and in interrelationships. 
Doings, sayings and relatings respectively accord with three arrangements. Doings accord with material-economic arrangements of work in the physical space; shared locations in space and time in which interaction in shared activity and work are possible. Sayings accord with cultural-discursive arrangements in the semantic space; shared language in which mutual understanding is possible. Finally, relatings accord with social-political arrangements in the social space; relatings, in which relationships are possible (e.g. relationships encompassing power and solidarity). These arrangements of practices 'hang together' in the 'project' of a practice; that is, the purpose of a practice that is revealed when a person sincerely answers the question 'What are you doing?'

Kemmis and his collaborators describe the three kinds of arrangements in which practices 'hang together' as 'practice architectures'. These practice architectures characteristic arrangements associated with practices of different kinds - 'prefigure' practices. They shape the unfolding of practices, although they do not predetermine them. They are necessary but not sufficient conditions for the conduct of a practice comprehensible as a practice of a certain kind. Kemmis et al. define a practice as:

a coherent and complex form of socially established cooperative human activity in which characteristic arrangements of actions and activities (doings) are comprehensible in terms of arrangements of relevant ideas in characteristic discourses (sayings), and when the people and objects involved are distributed in characteristic arrangements of relationships (relatings), and when this complex of sayings, doings and relatings

'hangs together' in a distinctive project. (2012, p. 26)

Practices thus involve 'practice landscapes' composed of these arrangements necessary for the conduct of a practice (arrangements that may already be found in the site - like the arrangements found in the curriculum of a university subject or in a lecture theatre), and 'practice traditions' that change and perhaps evolve over time in such a way that the practice reproduces and transforms itself to become adapted to changing times and local circumstances and also to sustain the arrangements that are the conditions of its possibility.

The arrangements of practices as defined by Kemmis et al. (2012) are referred to in several contributions of this special issue and are seen as an expression of the interplay between lifeworld and system, as well as between functional and substantive rationality. They express the intractability of the Education for All praxis. Sayings, then, refer to the language characteristic of Education for All practices. Doings refer to engaging in activities in the set-ups characteristic of Education for All practices. Finally, relatings refer to entering into relationships with other people and objects characteristic of Education for All practices.

\section{Summary and conclusion}

This special issue interprets the concept of Education for All as a matter of socially just education for all children - according to the UN Convention on the Rights of the Child - without any form of discrimination. It is therefore not about policy for specific target groups, such as students with special needs, but about the proactive creation of education, where differences between children are the norm instead of the exception. 
The key question for us is what mechanisms in the daily thinking and acting of teacher educators, teachers and pupils lead to Education for All as socially just education. This question is mainly explored through the lens of the 'doing' perspective in terms of Young's (1990) social justice theory, continental European pedagogy and the praxis model as formulated by Ax and Ponte (2008; see also GroundwaterSmith et al. 2012) and the concept of practice architectures as formulated by Kemmis and Grootenboer (2008), Kemmis et al. (2012) and Kemmis (2012). With the help of these concepts, we explore the abilities and possibilities that teacher educators and teachers actually have to realise socially just education in their daily work by focusing on the scope they are given to act autonomously and to take rational decisions with regard to the aims of their actions.

We stress, however, that the scope for autonomous action and the scope for rational decision-making are not only expressions of an already pre-figured situation; they also mirror the hope for change. The Education for All praxis is - in the words of Gadotti (1996) - promise and project at the same time. This is in line with what Sachs (2003) calls 'activist professionalism'. As she has observed, we need to transcend a conception of professionalism that is about simple 're-tooling' to one that places a premium on 're-imagining' professionalism. In such an approach, professionals do have the obligation to actively look for and enlarge their abilities and possibilities to realise Education for All within the context in which they act.

\section{References}

Aristotle., 1955. The Nichomachean ethics (J.A.K. Thomson, Trans.). London: Penguin.

Ax, J. and Ponte, P., 2008. Praxis: analysis of theory and practice. In: J. Ax and P. Ponte, eds. Critiquing praxis: conceptual and empirical trends in the teaching profession. Rotterdam: Sense, 1-18.

Ax, J. and Ponte, P., 2010. Moral issues in educational praxis: a perspective from pedagogiek and didactiek as human sciences in continental Europe. Pedagogy, culture and society, 18 (1), 29-42.

Biesta, G.J.J., 2010. Good education in an age of measurement: ethics, politics, democracy. Boulder, CO: Paradigm.

Bons, J.A.E. and Van Ophuijsen, J.M., eds., 1999. Aristotoles: ethica. (Dutch translation.). Groningen: Historische Uitgeverij.

Carr, W. and Kemmis, S., 1986. Becoming critical. London: The Falmer Press.

De Winter, M., 1995. Kinderen als medeburgers. Kinder- en jeugdparticipatie als maatschappelijk opvoedingsperspectief [Children as citizens. Child and youth participation as a social support perspective]. Utrecht: De Tijdstroom.

Detting, D. and Becker, M., 2009. Wie social ist Europa? Eine vergleichende Analyse der wichtigsten Indicatoren zur gesellschaftlichen Zukunftsfähigkeit der EU [How social is Europe? A comparative analysis of indicators important to social sustainability of the EU]. Berlin: Denktank Berlinpolis.

Freire, P., 1972. Pedagogy of the oppressed. Harmondsworth: Penguin.

Gadotti, M., 1996. Pedagogy of praxis: a dialectical philosophy of education. Albany: State University of New York Press.

Groundwater-Smith, S., et al., 2012. Facilitating practitioner research: developing transformational partnerships. London: Routledge.

Habermas, J., 1981. Theorie des kommunikativen handelns [Theory of communicative action]. Frankfurt, Germany: Suhrkamp.

Kemmis, S., 2012. Researching educational praxis: spectator and participant perspectives. British educational research journal, 38 (6), 885-905.

Kemmis, S. and Grootenboer, P., 2008. Situating praxis in practice: practice architectures and the cultural, social and material conditions for practice. In: S. Kemmis and T. Smith, eds. Enabling praxis: challenges for education. Rotterdam: Sense, 37-62. 
Kemmis, S. and Smith, T.J., eds., 2008. Enabling praxis. Challenges for education. Rotterdam: Sense.

Kemmis, S., et al., 2012. Ecologies of practices: learning practices. In: P. Hager, A. Lee, and A. Reich, eds. Learning practice. Dordrecht: Springer International, 33-49.

Luhmann, N., 1995. Social systems. San Francisco, CA: Stanford University Press.

Magalhães, A.M. and Stoer, S.R., 2009. Performance, citizenship and the knowledge society: a new mandate for European education policy. In: R. Dale and S. Robertson, eds. Globalisation \& Europeanization in education. Oxford: Symposium Books, 233-258.

Mannheim, K., 1940. Man and society in an age of reconstruction: studies in modern social structure. London: Routledge \& Kegan Paul.

Meuwese, S., Blaak, M., and Kaandorp, M., eds., 2005. Handboek Internationaal Jeugdrecht [Handbook of international juvenile law]. Nijmegen, The Netherlands: Ars Aequi Libri.

Neiman, S., 2008. Moral clarity: a guide for grown-up idealists. 1st ed. New York, NY: Harcourt.

Nickel, J., 1987. Making sense of human rights: philosophical reflections on the Universal Declaration of Human Rights. Berkeley: University of California Press.

Oancea, A. and Furlong, J., 2008. Expressions of excellence and the assessment of applied and practice-based research. In: J. Furlong and A. Oancea, eds. Assessing quality in applied and practice-based research in education: continuing the debate. London: Routledge, 1-19.

Ponte, P., 2007. Behind the vision: action research, pedagogy and development. In: A. Campbell and S. Groundwater-Smith, eds. An ethical approach to practitioner research: dealing with issues and dilemmas in action research. London: Routledge, $144-161$.

Ponte, P. and Ax, J., 2009. Action research and pedagogy as the science of the child's upbringing. In: S. Noffke and B. Somekh, eds. Handbook of educational action research. London: Sage, 324-335.

Ponte, P. and Ax, J., 2011. Inquiry-based professional learning in educational praxis: knowing why, what and how. In: N. Mockler and J. Sachs, eds. Rethinking educational practice through reflexive inquiry. Dordrecht: Springer, 49-61.

Raudenbush, S.W., 2009. The brown legacy and the O'Connor challenge: transforming schools in the images of children's potential. Educational researcher, 38 (3), 169-181.

Sachs, J., 2003. The activist teaching profession. Buckingham: Open University Press.

Schatzki, T., 2002. The site of the social: a philosophical account of the constitution of social life and change. University Park: University of Pennsylvania Press.

Schatzki, T.R., 2010. The timespace of human activity: on performance, society, and history as indeterminate teleological events. Lanham, MD: Lexington.

Schutz, A. and Luckmann, T., 1973. c1989. The structures of the life-world. Vol. 2. Evanston, IL: Northwestern University Studies in Phenomenology and Existential Philosophy.

UNESCO, 2000. The Dakar framework for action. Education for all: meeting our collective commitments [online]. World Education Forum closing document. Paris: UNESCO. Available from: http://unesdoc.unesco.org/images/0012/001211/121147e.pdf [Accessed 11 July 2011].

UNICEF/UNESCO, 2007. A human rights-based approach to Education for all [online]. New York / Paris: United Nations Children's Fund / United Nations Educational, Scientific and Cultural Organisation. Available from: http://unesdoc.unesco.org/images/ 0015/001548/154861e.pdf [Accessed 11 July 2011]

Van Manen, M., 1994. Pedagogy, virtue and narrative identity in teaching. Curriculum inquiry, 24 (2), 135-170.

Verhellen, E., Verschelden, G., and Vanthuyne, T., 1999/2000. Kinderrechten en non-discriminatie: het plaatselijke overleg non-discriminatie in het Gentse onderwijs [Child and non-discrimination: The local consultation on non-discrimination in education in Ghent]. Tijdschrift voor onderwijsrecht en onderwijsbeleid, 5, 335-350.

Weber, M., 1946, Dutch translation. Hans H. Gerth and C. Wright Mills, eds. Max Weber: essays in sociology. New York: Oxford University Press (first published in 1906-1924).

Young, I.M., 1990. Justice and the politics of difference. Princeton, NJ: Princeton University Press. 